\title{
Modeling Viruses' Isoelectric Points as a Milestone in Intensifying the Electrocoagulation Process for Their Elimination
}

\author{
Djamel Ghernaout ${ }^{1,2 *}$, Noureddine Elboughdiri1,3 \\ ${ }^{1}$ Chemical Engineering Department, College of Engineering, University of Ha'il, Ha'il, Saudi Arabia \\ ${ }^{2}$ Chemical Engineering Department, Faculty of Engineering, University of Blida, Blida, Algeria \\ ${ }^{3}$ Chemical Engineering Process Department, National School of Engineering, University of Gabes, \\ Gabes, Tunisia \\ Email: ^djamel_andalus@hotmail.com
}

How to cite this paper: Ghernaout, D. and Elboughdiri, N. (2021) Modeling Viruses' Isoelectric Points as a Milestone in Intensifying the Electrocoagulation Process for Their Elimination. Open Access Library Journal, 8: e7166.

https://doi.org/10.4236/oalib.1107166

Received: January 20, 2021

Accepted: February 4, 2021

Published: February 7, 2021

Copyright $\odot 2021$ by author(s) and Open Access Library Inc.

This work is licensed under the Creative Commons Attribution International License (CC BY 4.0).

http://creativecommons.org/licenses/by/4.0/

\section{(c) (i) Open Access}

\begin{abstract}
In both nature and physicochemical treatment, virus end depends on electrostatic interplays. Suggesting an exact method of predicting virion isoelectric point (IEP) would assist to comprehend and predict virus end. To predict IEP, an easy method evaluates the $\mathrm{pH}$ at which the total of charges from ionizable amino acids in capsid proteins reaches zero. Founded on capsid charges, however, predicted IEPs usually diverge by some $\mathrm{pH}$ units from experimentally measured IEPs. Such disparity between experimental and predicted IEP was ascribed to the electrostatic neutralization of predictable polynucleotidebinding regions (PBRs) of the capsid interior. In the first part of this work, models assuming the 1) impact of the viral polynucleotide on the surface charge, or 2) contribution of only exterior residues to surface charge are discussed. Such models are relevant to non-enveloped viruses only, and an identical model for enveloped viruses remains difficult by the deficiency of information on enveloped virus IEP and uncertainties concerning the effect of the phospholipid envelope on charge and ion gradients. It is difficult now that modeling IEPs for viruses could be employed in assessing the needed electric field application during electrocoagulation (EC) process. Parameters such as $\mathrm{pH}$ and aqueous matrix greatly influence IEPs and EC.
\end{abstract}

\section{Subject Areas}

Chemical Engineering \& Technology 


\section{Keywords}

Virus, Isoelectric Point (IEP), Electrophoretic Mobility (EM),

Electrocoagulation (EC), Electrochemical Disinfection (ED),

Electric Field (EF)

\section{Introduction}

In virus behavior and movement in natural and engineered mediums, electrostatic forces have a crucial contribution [1]. In water, the electric charge of organic macromolecules is a function of the ionic force and $\mathrm{pH}$ [2]. For such a reason, it is commodious to evaluate the isoelectric point (IEP) of the virus [3]. At the IEP, the net electric charge of the virion net charge is neutral (zero), when determining the possible impacts of electrostatic forces. Above their IEP, organic particles (like virions) possess a net negative charge because of deprotonated carboxyl groups; however, below the IEP, protonated amine groups give a net positive charge. Without taking into account the charge quantity, determining just the sign of a viral particle's charge could tell water treatment (like coagulation [4] [5], disinfection [6] [7], or membrane filtration [8]), modeling virus transfer across porous media [9], and virus sampling and level [10] [11] [12] [13].

Electrostatic forces are not the only decisive factor of virus behavior and transfer [1]. Indeed, additional interactions (like van der Waals forces, the hydrophobic impact, cation bridging, and steric interactions) have as well a crucial contribution in virus interplays with the surrounding medium [4] [8] [14]. On the other hand, IEP is not an ideal measure of electrostatic forces under all circumstances. At a distance from the IEP, electrophoretic mobility (EM) is very dependent on environmental circumstances like conductivity [8]. The IEP could not specify if a particular virus can shift conclusively between strong positive and negative surface charges below and above the IEP, or turn near zero charges over a wide $\mathrm{pH}$ range. Whereas electrostatic forces are not an ideal predictor of virus physi$\mathrm{cal} /$ chemical interactions (and IEP is not an ideal measure of electrostatic forces in all circumstances), IEP gives a valid and quantitative benchmark for contrasting ecological interplays of unlike viruses over a set of circumstances and exploratory techniques. Further, focusing on IEP permits handling the biggest distinctions between theoretical and empirical findings before suggesting a more adopted model to evaluate the extents of surface charge and potential.

A large numbers of trials have been performed to model the IEP of non-enveloped viruses founded on ionizable residues within capsid proteins [15] [16] [17] [18] [19]. Nevertheless, important contradictions appear between predicted IEPs founded on capsid proteins and empirically evaluated virus IEPs. Whilst empirical IEPs are frequently noted in the acidic interval ( $\mathrm{pH} 2$ - 5) [20], capsid proteome sequences often include equiponderant levels of amino acids mirroring pre- 
dicted IEPs near neutral pH [21]. Consequently, capsid amino acid composition alone could not explain virus IEP [1].

Numerous scientists have suggested electrostatic models of the virion to interpret the poor predictive level of ionizable amino acids [1]. Founded on a "soft colloid" model suggested by Duval and Ohshima [22], researchers [1] proposed that nucleic acids at the core of the virus capsid participate to overall virus surface charge. Researchers [19] presented an identical permeable virion model that measured the impact of capsid moieties founded on electrostatic screening of the surrounding environment. Both models propose that with augmenting permeability, buried components of the virion possess a bigger effect on the overall IEP [1] [19]. On the other hand, scientists [16] [18] proposed that only exterior residues participate to the surface charge; therefore, heterogeneous distribution of positive and negative amino acid charges inside the capsid coat lead to greater or lower IEP levels. Božič et al. [17] also estimated a one- or two-shell model of virion surface charge to explain heterogeneity in ionizable amino acid distribution, still the model was particularly used to experimenal IEP estimates only for bacteriophage PP7 [23]. Whereas the discussion concerning basic assumptions could be polarizing, not all parts of such models are opposed.

Lately, Heffron and Mayer [2] [24] proposed a differing procedure to modeling non-enveloped virion IEP founded not on a sole electrostatic model of the virion, but rather on the changing magnitude of electrostatic interplays between the capsid and the viral genome. As many of the viruses with the biggest difference between predicted and empirical IEPs displayed great capsid regions dedicated to binding the viral polynucleotide, Heffron and Mayer [2] assumed that the charges of these polynucleotide-binding regions (PBRs) and bound sections the viral polynucleotide itself are mutually neutralized. Heffron and Mayer [2] also predicted the location of PBRs from virus capsid proteome sequences to predict the IEP of viruses whose detailed capsid structures were obscure. Such procedure advocated remarks of Šiber et al. [25] that the two-shell model of Božič et al. [17] was convenient for spontaneously assembling viruses with strong, nonspecific interactions between capsid proteins and ssRNA. Nevertheless, the PBR exclusion procedure displayed amelioration in IEP prediction for dsDNA viruses as well as ssRNA viruses [1] [2].

Heffron and Mayer [1] assessed the capacity of polynucleotide effect and exterior residue theories for suggesting a model of non-enveloped, icosahedral virus IEPs, as juxtaposed to the freshly presented hypothesis of PBR exclusion. They reviewed models proposing polynucleotide impact in light of empirical evidence. They examined the theory that external capsid residues participate disproportionately to global charge employing 3D capsid structures for 26 viruses with known (empirical) IEPs. They examined Heffron and Mayer's procedure of excluding PBRs, as well as the model of virion charge structure that arises from the PBR exclusion procedure. They examined the possibility of such competing theories for suggesting a predictive IEP model, as well as the impediments to implementing such a model to enveloped viruses. 
This work discusses supplementary considerations for a predictive IEP model especially those related to enveloped viruses and interactions between viruses and the surrounding medium. A special interest is accorded to electrocoagulation (EC) process intensification for better eliminating viruses. A brief description is given about similarities related to charge neutralization of natural organic matter (NOM) and viruses. As an illustration of the successful implementation of the EC process, a brief review of this technique as a tertiary treatment of municipal wastewater is presented focusing on microbial removal pathways. A question is suggested and replied about if viruses' IEPs modeling will be employed in assessing the needed electric field (EF) application.

\section{Additional Considerations for a Predictive Isoelectric Point (IEP) Model}

\subsection{Considerations for Enveloped Viruses}

Actual models of virion charge stay restricted to non-enveloped, icosahedral virions [1]. Ecological persistence of viruses with phospholipid envelopes, like severe acute respiratory syndrome coronavirus 2 (SARS-CoV-2) [26] [27] [28], is usually regarded as not enough to be important to transport or water and wastewater treatment [29] [30] [31]. For such cause, only non-enveloped viruses were taken into account here, excepting bacteriophages PM2 [PM2] and PRD1 [PRD1], which carry an internal lipid membrane [32] [33]. Nevertheless, several enveloped viruses, particularly those transmitted through the fecal-oral way (like avian influenza virus), could persevere for months in aqueous habitats [34] [35] [36]. Moreover, the electrostatic charge of enveloped viruses could tell virus removal through air filtration and deposition on surfaces [37] [38].

Regrettably, enveloped viruses constitute unique dares to IEP prediction [1]. Envelope phospholipids could participate considerably to surface charge, and the low dielectric constant of phospholipid bilayers could lower their apparent $\mathrm{p} K_{\mathrm{a}}$ by as much as one $\mathrm{pH}$ unit [39]. The variety of phospholipids in virus envelopes can as well challenge efforts for a predictive model. Researchers [40] quantified over 125 various phospholipids from three strains of influenza virus and discovered that the composition of lipids in the virion envelopes varied not only from the host cell membrane but as well between virus strains. Because these phospholipids are obtained from the host, the complex lipid profiles are not predictable from the viral genome. Virions could earn else materials from the host as well. As an illustration, human papillomavirus obtains histones from the host that stabilize the polynucleotide inside the capsid [41]. Such structures are also not coded for in the viral genome, yet could affect global capsid charge via neutralizing the polynucleotide charge.

Probably most conclusive is that empirical IEP data for enveloped viruses are very sparse, with a poor agreement between sources [1]. Unluckily, only three genera are represented in Michen and Graule's exhaustive review of empirical IEP data [20]; however, IEPs of isolated proteins (and particularly glycoproteins) 
from enveloped viruses are more frequent [1]. Empirical IEPs for numerous strains of Orthopoxvirus are obtainable; however, much of the data comes from two research groups with a poor agreement, even when juxtaposing the same virus strains [42]. As before noted for non-enveloped viruses [2], IEP quantifications founded on EM were more acidic than quantifications performed by isoelectric focusing or else manners. Nevertheless, the manner of quantification was confused by the source. Douglas et al. [43] [44] carried out the majority of enveloped virus EM quantifications, while Mouillot and Netter [45] were in charge of the majority of isoelectric focusing quantifications [20] [42]. As mentioned by Michen and Graule [20], Douglas et al. [43] [44] employed a more accurate purification technique than Mouillot and Netter [45]. Nevertheless, Douglas et al. [43] [44] carried out tests in molar sucrose, which may have influenced virion charge, aggregation, and EM [44]. Consequently, it is hard to decide if there is a veritable difference between the two procedures. Moreover, poxviruses could possess diverse infectious forms and several membrane-embedded proteins [46]. For suggesting a theory of enveloped virus IEP, the prime concern has to be gathering empirical IEP estimates for strains of viruses with one or two well-defined membrane proteins (like coronaviruses or influenza A virus [47] [48]). Nevertheless, the broad variety in envelope proteins between strains could still constitute a dare to extrapolation of a model to novel viruses.

\subsection{Interactions between Viruses and the Surrounding Medium}

In the water matrix, ions could bind to moieties on the capsid surface, that way changing surface charge [1]. This is particularly correct for multivalent ions like calcium and phosphate [20] [49], which could even be kept after viruses are transferred from the propagation/storage solution [9]. In addition to ions from the surrounding environment, polyvalent cations are inherent to the structure of several viruses. Such ions could greatly modify IEP, and can be so inherent as to be eliminated only by way of denaturation [50]. Among the viruses, five viruses (BP29, CPaV2, PM2, REO3, and SRVA) possess zinc, magnesium, and/or calcium-binding sites listed in the UniProt database (Table 1) [51]. Particularly, Simian rotavirus A (SRVA) possessed numerous cation-binding sites that can participate to the higher than predicted IEP. Such inherent ions, in addition to polyvalent counterions kept in the core, may possess a substantial influence on the global charge of several viruses. Nevertheless, the level to which such cations modify surface charge, as well as the irreversibility of numerous cation-binding sites, stays to be evaluated.

Virions could as well possess a more nuanced permeability than models of soft or hard colloids [1]. As an illustration, many viruses (like human rhinovirus, southern bean mosaic virus and Mengo encephalomyocarditis virus) possess selective cation channels located at capsid vertices [54] [55]. Further, bacteriophage MS2 possesses pores at its fivefold axes that are ringed by disordered loops with a single glutamic acid at the apex [1]. The negative charge of these loops above $\mathrm{pH} 4$ could assist in selective diffusion of cations into the virion 
Table 1. Classification and abbreviations for viruses, as previously employed in Heffron and Mayer [2].

\begin{tabular}{|c|c|c|c|c|c|c|}
\hline Abbreviation & Species & Genus & $\begin{array}{c}\text { Nucleic } \\
\text { Acid }\end{array}$ & $\begin{array}{l}\text { NCBI } \\
\text { Taxon }^{1}\end{array}$ & PDBID $^{2}$ & $\begin{array}{l}\text { Resolution } \\
(\AA)\end{array}$ \\
\hline AAV4 & $\begin{array}{l}\text { Adeno-associated } \\
\text { virus } 4\end{array}$ & Dependoparvovirus & ssDNA & 57,579 & $2 \mathrm{~g} 8 \mathrm{~g}$ & 3.2 \\
\hline BDMV & $\begin{array}{l}\text { Belladonna } \\
\text { mottle virus }\end{array}$ & Tymovirus & ssRNA & 12,149 & - & - \\
\hline BP29 & Bacillus phage $\Phi 29$ & Salasvirus & dsDNA & 10,756 & - & - \\
\hline CCMV & $\begin{array}{l}\text { Cowpea chlorotic } \\
\text { mottle virus }\end{array}$ & Bromovirus & ssRNA & 12,303 & $1 \mathrm{cwp}$ & 3.2 \\
\hline CMV & $\begin{array}{c}\text { Cucumber mosaic } \\
\text { virus }\end{array}$ & Cucumovirus & ssRNA & 12,307 & $1 \mathrm{f} 15$ & 3.2 \\
\hline $\mathrm{CPaV} 2$ & Canine parvovirus 2 & Protoparvovirus & ssDNA & 10,790 & - & - \\
\hline $\mathrm{CPaV}^{3}$ & $\begin{array}{c}\text { Feline } \\
\text { panleukopenia virus }\end{array}$ & Protoparvovirus & ssDNA & 10,787 & $1 \mathrm{c} 8 \mathrm{~g}$ & 3.0 \\
\hline CRPV & $\begin{array}{l}\text { Cottontail rabbit } \\
\text { papillomavirus }\end{array}$ & Kappapapillomavirus & dsDNA & 31,553 & - & - \\
\hline $\mathrm{CRPV}^{3}$ & $\begin{array}{c}\text { Human } \\
\text { papillomavirus } 16\end{array}$ & Alphapapillomavirus & dsDNA & 333,760 & $5 \mathrm{keq}$ & 4.3 \\
\hline CXA21 & $\begin{array}{c}\text { Coxsackievirus } \\
\text { A21 }\end{array}$ & Enterovirus & ssRNA & 12,070 & $1 \mathrm{z} 7 \mathrm{~s}$ & 3.2 \\
\hline CXB5 & $\begin{array}{c}\text { Human } \\
\text { coxsackievirus B5 }\end{array}$ & Enterovirus & ssRNA & 103,907 & - & - \\
\hline $\mathrm{CXB}^{3}$ & $\begin{array}{c}\text { Human } \\
\text { coxsackievirus B3 }\end{array}$ & Enterovirus & ssRNA & 103,904 & $1 \mathrm{cov}$ & 3.5 \\
\hline EBFR & $\begin{array}{c}\text { Enterobacteria } \\
\text { phage fr }\end{array}$ & Levivirus & ssRNA & 12,017 & 1 frs & 3.5 \\
\hline EBGA & $\begin{array}{c}\text { Enterobacteria } \\
\text { phage GA }\end{array}$ & Levivirus & ssRNA & 12,018 & 1gav & 3.4 \\
\hline EBMS2 & $\begin{array}{l}\text { Enterobacteria } \\
\text { phage MS2 }\end{array}$ & Levivirus & ssRNA & 329,852 & $2 \mathrm{~ms} 2$ & 2.8 \\
\hline EBQB & $\begin{array}{c}\text { Enterobacteria } \\
\text { phage } \mathrm{Q} \beta\end{array}$ & Allolevivirus & ssRNA & 39,803 & 5vly & 3.3 \\
\hline EBSP & $\begin{array}{c}\text { Enterobacteria } \\
\text { phage SP }\end{array}$ & Allolevivirus & ssRNA & 12,027 & - & - \\
\hline ECV1 & Echovirus 1 & Enterovirus & ssRNA & 103,908 & lev1 & 3.6 \\
\hline ELV & $\begin{array}{l}\text { Erysimum } \\
\text { latent virus }\end{array}$ & Tymovirus & ssRNA & 12,152 & - & - \\
\hline HAdV5 & $\begin{array}{c}\text { Human } \\
\text { adenovirus } 5\end{array}$ & Mastadenovirus & dsDNA & 28,285 & $4 \mathrm{v} 4 \mathrm{u}$ & 10 \\
\hline HHAV & Hepatitis A virus & Hepatovirus & ssRNA & 12,098 & $4 q \mathrm{pi}$ & 3.0 \\
\hline HRV2 & Human rhinovirus 2 & Enterovirus & ssRNA & 12,130 & $1 \mathrm{fpn}$ & 2.6 \\
\hline MEV & $\begin{array}{c}\text { Mengo } \\
\text { encephalomyocarditis } \\
\text { virus }\end{array}$ & Cardiovirus & ssRNA & 12,107 & $2 \mathrm{mev}$ & 3.0 \\
\hline
\end{tabular}




\begin{tabular}{|c|c|c|c|c|c|c|}
\hline Continued & & & & & & \\
\hline NOR1 & Norwalk Virus & Norovirus & ssRNA & 524,364 & lihm & 3.4 \\
\hline PHIX & $\begin{array}{c}\text { Enterobacteria } \\
\text { phage } \Phi \times 174\end{array}$ & Sinsheimervirus & ssDNA & 10,847 & $2 \mathrm{bpa}$ & 3.0 \\
\hline PM2 & $\begin{array}{c}\text { Pseudoalteromonas } \\
\text { phage PM2 }\end{array}$ & Corticovirus & dsDNA & 10,661 & $2 \mathrm{w} 0 \mathrm{c}$ & 7.0 \\
\hline POL1 & Poliovirus & Enterovirus & ssRNA & 12,081 & $1 \mathrm{hxs}$ & 2.2 \\
\hline PRD1 & $\begin{array}{l}\text { Enterobacteria } \\
\text { phage PRD1 }\end{array}$ & Alphatectivirus & dsDNA & 10,658 & $1 w 8 x$ & 4.2 \\
\hline RCNM & $\begin{array}{c}\text { Red clover necrotic } \\
\text { mosaic virus }\end{array}$ & Dianthovirus & ssRNA & 12,267 & $6 \mathrm{mrm}$ & 2.9 \\
\hline REO3 & Reovirus 3 & Orthoreovirus & dsRNA & 10,886 & $2 \mathrm{cse}$ & 7.0 \\
\hline SBMV & $\begin{array}{l}\text { Southern bean } \\
\text { mosaic virus }\end{array}$ & Sobemovirus & ssRNA & 652,938 & $4 \mathrm{sbv}$ & 2.8 \\
\hline ScrMV & $\begin{array}{l}\text { Scrophularia } \\
\text { mottle virus }\end{array}$ & Tymovirus & ssRNA & 312,273 & - & - \\
\hline SRVA & Simian rotavirus A & Rotavirus & dsRNA & 450,149 & $4 v 7 \mathrm{q}$ & 3.8 \\
\hline TBMV & Tobacco mosaic virus & Tobamovirus & ssRNA & 12,243 & - & - \\
\hline TYMV & $\begin{array}{l}\text { Turnip yellow } \\
\text { mosaic virus }\end{array}$ & Tymovirus & ssRNA & 12,154 & lauy & 3.0 \\
\hline
\end{tabular}

${ }^{1}$ NCBI Taxon: National Center for Biotechnology Information (www.ncbi.nlm.nih.gov) taxonomical ID [52]. ${ }^{2}$ PDBID: Protein Data Bank (rcsb.org) ID used for 3D structural comparisons [53]. ${ }^{3}$ Alternate species/strain used for 3D structure only.

core, and can aid in recruiting and holding counterions to stabilize the negatively charged polynucleotide. This pathway would further demonstrate the shortage of impact of the viral genome on virion charge.

All the preceding factors may complicate a predictive model of virus IEP [1]. Whether a model could successfully combine or safely ignore such virion complexities constitutes significant future research. Nevertheless, every confounding factor for a single model of virion charge lends support for a procedure such as PBR exclusion that identifies functional virion structures rather than universally applying a simplified physical model. With expanded empirical IEP data, more accurate IEP prediction can be feasible founded on conserved virion structures. The PBR exclusion model possesses implementations in water and wastewater treatment, as well as virus transport and microbial source tracking. As a general heuristic, viruses relying on electrostatic interactions between the polynucleotide and capsid proteins are more probable to possess acidic IEPs outside the circumneutral range expected from the sum of ionizable capsid residues. Therefore, scientists could profit from the insights of the PBR exclusion method, even without identifying known PBRs or employing the PBR prediction method suggested by Heffron and Mayer [2]. Future research has to merge PBR exclusion into a quantitative model for virus surface charge. Moreover, the PBR exclusion method furnishes rise to a conceptual electrostatic model of the virion that better 
unifies empirical evidence of virion structure and morphogenesis. Such a conceptual model is not an $a b$ ovo assumption to account for a small subset of aberrant viruses. Instead, the PBR model follows from the success of the PBR exclusion method in accounting for both empirical IEPs that align with capsid residue composition, as well as empirical IEPs that change considerably. Additional confirmation and refinement of this electrostatic model, particularly concerning the ionic composition of the virion core, could have far-reaching importance for structural virology in general [1].

\section{Electrocoagulation (EC) Process Intensification for Better Killing Viruses}

In the field of killing pathogens existing in water, if there is a method that has attracted huge attention from water treatment specialists it is the electrocoagulation (EC) process [56]. During the last two decades and thanks to its techno-economic benefits, this electrochemical technology has been the subject of many hundreds of researches and patents published throughout the entire world [57] [58]. The generally accepted tendency concerning the usage of the EC technique is to employ it as an integrated step with additional processes [59]. In the field of killing microorganisms, EC process is frequently inserted as a pre-stage before electrooxidation (EO) method in the treatment train [60] [61]. For such a combination, more important virus reduction is possibly reached via the collective actions of physical removal by coagulation/filtration, ferrous iron-based disinfection [62] [63] [64], and EO disinfection [65]. In this context, much more research needs to be realized to distinguish among the electric field (EF) and cohesion contributions [66]. Furthermore, more investigation has to be pointed on evaluating the more and more probable production of the hydroxyl radical $\left({ }^{\circ} \mathrm{OH}\right)$ during the EC technology [67] [68] [69]. Like in the chemical water disinfection, on the other hand, identical problems such as disinfection by-products (DBPs) generation have also appeared in the EC applications [70] [71] [72]. More research needs to be pointed into such directions [73] [74] [75].

As mentioned above, bacteria and viruses show a tendency to adsorb onto surfaces such as activated carbon, fibrous carbon, or ion exchange resins. This tendency is driven mainly by electrostatic forces between charged groups on the cell wall and on the adsorbent [57].

Several mechanisms have been proposed to account for the lethality of electrochemical exposure including: 1) oxidative stress and cell death due to electrochemically generated oxidants ("killer" agents such as ${ }^{\bullet} \mathrm{OH}$ ), 2) irreversible permeabilisation of cell membranes by the applied EF [76] [77] [78], and 3) electrochemical oxidation of vital cellular constituents during exposure to electric current [79] or induced EFs [57] [80] [81].

Throughout the EC method, employing $\mathrm{Fe} / \mathrm{Al}$ anodes, physical elimination and chemical deactivation pathways are suggested for bacteria reduction procedure: 1) entrapping pathogens in flocs, 2) destabilizing negatively charged microbes through sweep flocculation [82], and 3) demobilizing bacteria cell enve- 
lopes upon electrochemically formed reactive oxygen species (ROSs) or direct impact of the EF [76] [83] [84] [85]. Deepest investigation works on microbes' removal through EC are more called to promote the industrial applications of this performant technology.

\section{Similarities with Charge Neutralization of Natural Organic Matter (NOM) and Viruses}

Since they are negatively charged, there are analogies between natural organic matter (NOM) and microorganisms in terms of their removal via charge neutralization mechanism during chemical coagulation (CC) and EC processes (Figure 1 and Figure 2). EC as efficient technique in mineral and organic matters removal [86] [87] [88] has been proven also performant in pathogens (including Escherichia coli and viruses) removal [89]. Therefore, this electrochemical process is promising water treatment technology even if more studies must be done about the best choice of EC electrodes [90] [91]. For instance, anode in iron (Fe) and cathode in metal that does not produce chlorine in water stream to avoid DBPs formation since it was eventually demonstrated that even at very low chloride concentrations (less than $100 \mathrm{mg} / \mathrm{L}$ ) sufficient free chlorine can be produced to efficiently disinfect water [57] [92] [93].

Several researchers focused on promoting the large industrial usage of EC as a green technology [94] [95] [96]. Concerning EC process design, the focus should be accorded to intensify the EC device in terms of residence time and close contact opportunities between water pollutants and electrodes area. The laminar vs. turbulent regime should be given more interests to better increase the metallic cations liberation from the anode and avoid or reduce the passivation of the electrodes. Evolution of hydrogen form cathode and oxygen from anode should be well optimized; at the same time, chlorine emanation from anode should be avoided or decreased to avoid DBPs generation [97] [98] [99]. Moreover, increasing

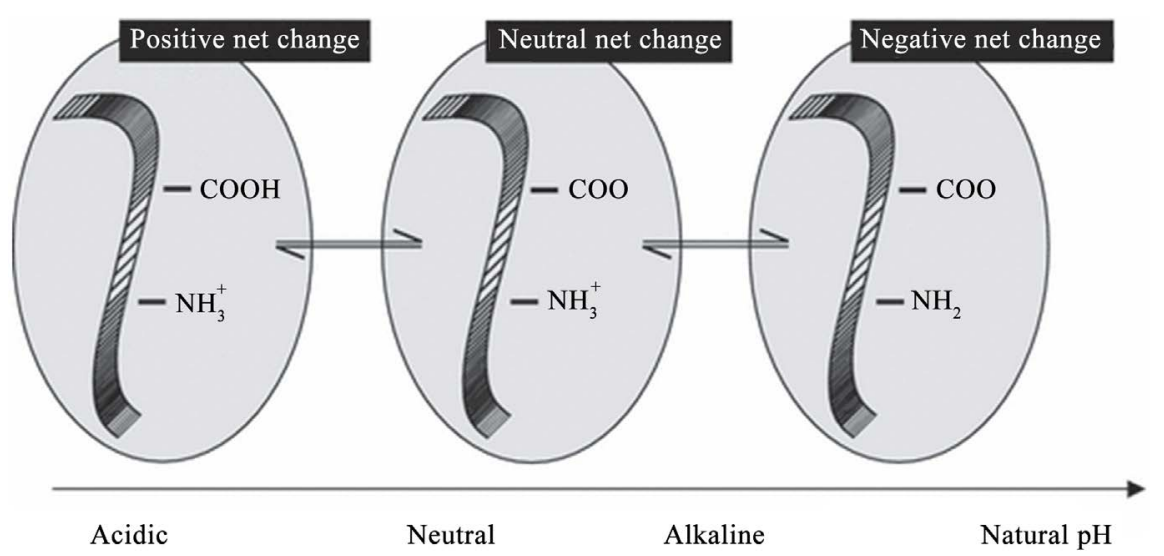

Figure 1. Schematic showing the protonation states of functional groups on a protein sector as a function of $\mathrm{pH}$. The carboxyl and amino functional groups are in equilibrium with the $\mathrm{H}_{3} \mathrm{O}^{+}$concentration and thus alter their charge if the environmental $\mathrm{pH}$ is changed. The net charge of a protein (or protein sector) is therefore determined by the superposition of the protonated and unprotonated states of its functional groups [20]. 


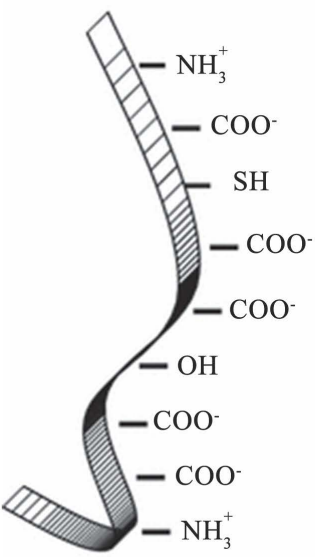

(a)

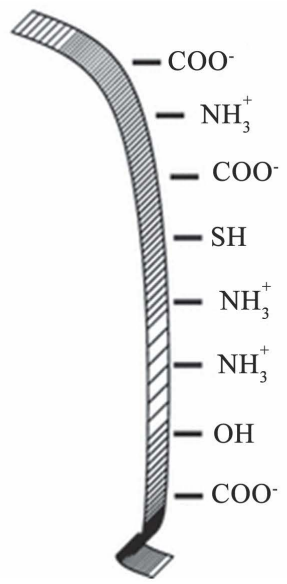

(b)

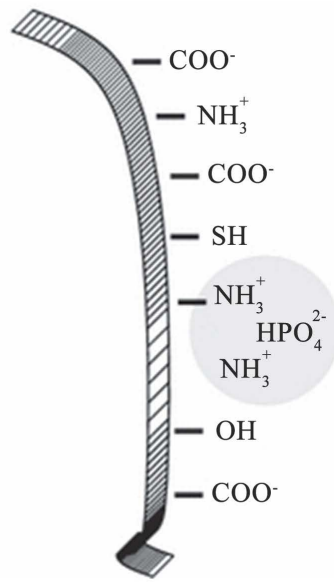

(c)

Figure 2. Sketches coat protein segments of different viruses and the arrangement of their functional groups. The environmental $\mathrm{pH}$ for all three schematic draws is assumed to be neutral. In (a) and (b), we compare the occurrence of different types of functional groups on two different coat proteins leading to a difference in virus isoelectric point (IEP). While in (a) the deprotonated carboxyl groups are superior, in (b) these negatively charged groups are balanced out by a relative higher number of protonated amino groups. Hence, (a) shows a section of a coat protein which belongs to a virion having an IEP in the acid regime, whereas the draw in (b) refers to a virion possessing an IEP at neutral $\mathrm{pH}$. In (c) the identical coat protein is sketched as in (b) including the illustration of surface complexation or specific adsorption (marked with the gray circle) and thus the water chemistry-dependent IEP alteration. The effect is shown using a hydrogen phosphate ion that binds with their oxygen atoms to the hydrogen atoms of the amino functional group. Hence, neutralizing the prior positive charge and leading to a relative decrease in the IEP of the virion when compared with (b) [20].

the water temperature using solar energy heating would enhance the EC process efficiency technically, energetically, and economically [100]. The heated EC proess combines EC with distillation (or its similar version, even if at low temperature between $20^{\circ} \mathrm{C}-100^{\circ} \mathrm{C}$ ) or membrane distillation using solar radiation [101] [102]. Finally, the EC method remains promising vis-a-vis pathogen removal and water treatment in a general manner [103] [104] [105].

\section{Iron Electrocoagulation (Fe-EC) as a Tertiary Treatment of Municipal Wastewater}

Bicudo et al. [106] estimated the possibility of low voltage iron electrocoagulation (Fe-EC) as a technology for treating municipal secondary effluent treatment. They concentrated on eliminating microbial indicators, antibiotic resistant bacteria (ARB), and nutrients. They employed charge dosage $(\mathrm{CD})$ and charge dosage rate $(\mathrm{CDR})$ as the major process control variables. Tests with synthetic secondary effluent illustrated $>4 \log _{10}$ and $>5 \log _{10}$ removal for phage $\Phi X 174$ and for E. coli WR1, respectively. In real effluents, bacterial indicator removal exceeded $3.5 \log _{10}$, ARB were removed below detection limit $\left(\geq 2.5 \log _{10}\right)$, virus removal reached $2.3 \log _{10}$ and Clostridium perfringens spore removal exceeded $2.5 \log _{10}$. In both real and synthetic wastewater, trials depicted that bacterial removal augmented 
with increasing $\mathrm{CD}$ and decreasing $\mathrm{CDR}$. Virus elimination augmented with increasing $\mathrm{CD}$ even if it was irresponsive to $\mathrm{CDR}$. Further, $C$. perfringens spore reduction increased with augmenting $\mathrm{CD}$ yet attained a removal plateau, being also irresponsive to CDR. Phosphate removal exceeded 99\%, while total nitrogen and chemical oxygen demand removals were below $15 \%$ and $58 \%$, respectively. Operational cost estimates were made for power and iron plate consumption, and were found to be in the range of 0.01 to $0.24 € / \mathrm{m}^{3}$ for the different assayed configurations. Consequently, low voltage Fe-EC is a promising technology for pathogen removal of secondary municipal effluents, with log 10 removals comparable to those obtained by traditional disinfection methods like chlorination, UV, or ozonation.

\subsection{Influence of Water Matrix on Electrocoagulation (EC) Performance}

Bicudo et al. [106] proved the impact of water matrix (synthetic vs. real secondary effluent) for bacteria and virus indicator elimination by EC, as well as nutrient reduction. In real secondary effluents, $E$. coli reduction was $1-2 \log _{10}$ smaller than that noted for $E$. coli in synthetic effluents, even when the Fe injection was doubled. Identical remarks were noted concerning phage $\Phi X 174$, with reduction also dropping by $1-2 \log _{10}$ in real secondary effluents. Even if the response reached with synthetic and real secondary effluent was identical in qualitatively, reduction attained for $E$. coli and phage $\Phi$ X174 still differs by orders of magnitude.

It was suggested that the complexity of the water matrix from real secondary effluents, and its bigger level of organic matter, iron-scavenging anions and complexation agents (like phosphates, citrates, carbonates and sulfates) are in charge of considerably reduced coagulant formation or microbial eliminations [5] [84] [106] [107].

Such chemicals are known to be in charge of hindering $\mathrm{Fe}^{2+}$ oxidation into dissolved $\mathrm{Fe}^{3+}$, thus reducing coagulant precipitation and subsequent sweep flocculation [106]. Anfruns-Estrada et al. [108] only estimated C. perfringens spore reduction in real secondary effluents, illustrating identical features quantitatively and qualitatively with previous Fe-EC research performed in real sewage and secondary effluents.

\subsection{Microbial Removal Pathways}

Bicudo et al. [106] noticed that eliminating all bacterial indicators was globally identical without taking into account their resistance to antibiotics or their Gram classification, with the reduction being highly dependent on the quantity and speed of Fe liberation. Identical remarks remain as well true for somatic coliphages (even if seeming less sensitive to the rate of dosage), even if do not totally apply for $C$. perfringens spores. This indicates a variable response to the Fe-EC process for each type of microorganism.

Bicudo et al. [106] recognized three routes for pathogens removal, that is 1) 
enmeshment (or adsorption) in the $\mathrm{Fe}(\mathrm{OH})_{2(\mathrm{~s})} / \mathrm{Fe}(\mathrm{OH})_{3(\mathrm{~s})}$, and elimination via deposition; 2) demobilization due to generation of ROSs or killing agents; and 3) killing due to EF. Enmeshment is largely viewed as the controlling reduction route of microorganisms [83] [84] [106] [109] [110]. This is widely attributed to the affinity of their surface functional groups, like teichoic acids and phospholipids, with the EC flocs. Such functional groups are observed in identical quantities in Gram-positive and Gram-negative bacterial cell walls [109]. Virus elimination has been assigned to both $\mathrm{Fe}(\mathrm{OH})_{2(\mathrm{~s})} / \mathrm{Fe}(\mathrm{OH})_{3(\mathrm{~s})}$ enmeshment [5] [111], and demobilization via either ROSs or chlorine-based oxidants produced through anodic reduction [5] [106] [112].

As mentioned by Bicudo et al. [106] concerning CDR contribution in favoring either of the previously mentioned removal route, Heffron et al. [113] matched $\mathrm{Fe}^{2+}$ oxidation rate and bacteriophage elimination. Quick oxidation of $\mathrm{Fe}^{2+}$ conducts to a shorter exposure period and thus poorer contact between the phages and the reactive iron species, resulting in a less significant killing [113]. Such findings suggest that ROSs formed during $\mathrm{Fe}^{2+}$ oxidation are a prime contributor in killing pathogens throughout Fe-EC, with the influence of these being stronger for slowly occurring oxidations. Bicudo et al. [106] noticed that the adopted overnight settling for all tests probably affects $\mathrm{O}_{2(\mathrm{~g})}$ diffusion into the effluent enhancing the slow $\mathrm{Fe}^{2+}$ oxidation, thus considerably influencing the elimination. Bicudo et al. [106] noted for both synthetic and real effluents an augmenting reduction performance for bacterial and viral indicators under reducing CDRs (less important for viruses), even when the quantity of liberated iron was similar. The noticed dependency of microorganisms' elimination on CDR proposes that the formation of ROSs may be really a controlling parameter in the course of Fe-EC. During the anode oxidation, the aerobic oxidation of $\mathrm{Fe}^{2+}$ liberated generates a series of reactive species that comprises superoxide ion $\left({ }^{\bullet} \mathrm{O}_{2}^{-}\right)$, hydrogen peroxide $\left(\mathrm{H}_{2} \mathrm{O}_{2}\right)$ and hydroxyl radical $\left({ }^{\bullet} \mathrm{OH}^{-}\right)$[114] [115], all of which are renowned to possess killing potentials [111] [112]. This involves that microbial elimination by Fe-EC could be really an integration of physical separation and chemical demobilization, and not just an adsorption-sedimentation process [106]. It can as well clarify why spores (dormant bacterial structures, highly resistant to chemical attack) are notably less touched than bacterial indicators by changing CD or CDR [106].

Researchers [69] discussed the advanced oxidation process (AOP) phenomena in EC process. AOPs have been widely described as near ambient temperature treatment techniques founded on highly reactive radicals, especially ${ }^{\bullet} \mathrm{OH}^{-}$as the main oxidant. Since water-containing colloidal particulates, oils, or other contaminants move through the applied EF, there may be ionization, electrolysis, hydrolysis, and free-radical formation that could modify the physicochemical characteristics of water and pollutants. When the EC device run at a high cell potential and an anodic process takes place in the potential region of water discharge, ${ }^{\bullet} \mathrm{OH}^{-}$is produced. To increase considerably the possibilities to form free radicals during EC, ultrasound coupled with EC could be very helpful as noted 
by some scientist [69]. Moreover, EC process at $\mathrm{pH} \leq 3$ possesses more probability to generate hydroxyl radicals. Table 2 presents the detailed Fe-EC reactions in the case of $\mathrm{Fe}$ (and $\mathrm{Al}$ for comparison purpose) [61]. At $\mathrm{pH}$ at $\mathrm{pH} \leq 3$ (Table 2), $\mathrm{O}_{2(\mathrm{~g})}$ is generated besides $\mathrm{Fe}^{2+}$ liberation at the anode. Such conditions seem to be more favorable to ${ }^{\bullet} \mathrm{OH}^{-}$production even if there is no evidence of the occurrence of AOP phenomena and more research remains required dealing with free radicals generation in EC process [60] [67] [68] [69].

\section{Using Viruses' Isoelectric Points (IEPs) Modeling in Assessing the Needed Electric Field (EF) Application}

As seen above, the EF contribution in ED generally and EC particularly remains fundamental since EF is poisonous to microbial cells [76] [116]. Microorganisms are electrically charged, like NOM, this why the EF action is fundamental in EC process [117] [118]. As shown previously, modeling IEPs for viruses is crucial in understanding their behavior in aquatic medium. Evaluating the required EF application, in terms of intensity and residence time, for their elimination during electrochemical treatment is also important. A question may arise here: what if modeling IEPs for viruses will be employed in assessing the needed EF application?

In this direction, Heffron et al. [5] estimated human virus alleviation and quantitatively evaluated the death of viruses in Fe-EC (Figure 3). They affirmed that the complexity of natural water matrices deserves more experimentation of

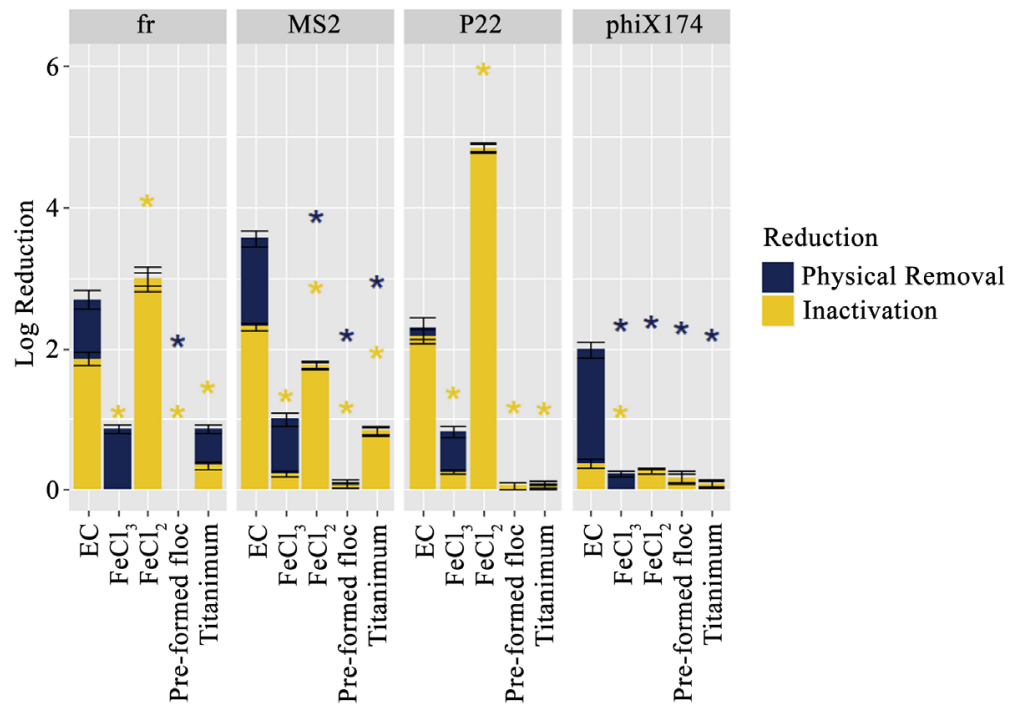

Figure 3. Mechanisms of bacteriophage mitigation due to electrocoagulation (EC), chemical coagulation (CC), adsorption and electrooxidation (EO). Inactivation and physical removal were compared between $\mathrm{EC}, \mathrm{CC}$ with ferric chloride $\left(\mathrm{FeCl}_{3}\right), \mathrm{CC}$ with ferrous chloride $\left(\mathrm{FeCl}_{2}\right)$, flocs formed by EC prior to the addition of bacteriophages (pre-formed floc), and EO with inert titanium electrodes (Titanium). Asterisks indicate a significant difference in log reduction from EC due to physical removal (blue asterisk) or inactivation (yellow asterisk). Error bars represent standard error of the mean of triplicate tests $[5]$. 
Table 2. EC mechanisms using $\mathrm{Fe}(\mathrm{pH} \mathrm{2,} 7$ and 12) and $\mathrm{Al}(\mathrm{pH} 7)$ electrodes [61].

\begin{tabular}{|c|c|}
\hline & Fe mechanisms \\
\hline \multirow{9}{*}{ Mechanism \#1 (pH 2) } & Anode: \\
\hline & $2 \mathrm{Fe}_{(\mathrm{s})}-4 \mathrm{e}^{-} \rightarrow 2 \mathrm{Fe}_{(\mathrm{aq})}^{2+}\left(E^{\circ}=+0.447 \mathrm{~V}\right)$ \\
\hline & $2 \mathrm{H}_{2} \mathrm{O}_{(1)}-4 \mathrm{e}^{-} \rightarrow \mathrm{O}_{2(\mathrm{~g})}+4 \mathrm{H}_{(\mathrm{aq})}^{+}\left(E^{\circ}=-1.229 \mathrm{~V}\right)$ \\
\hline & Solution: \\
\hline & $2 \mathrm{Fe}_{(\text {aq })}^{2+}+4 \mathrm{OH}_{(\mathrm{aq})}^{-} \rightarrow 2 \mathrm{Fe}(\mathrm{OH})_{2(\mathrm{~s})}$ \\
\hline & Cathode: \\
\hline & $8 \mathrm{H}_{(\mathrm{aq})}^{+}+8 \mathrm{e}^{-} \rightarrow 4 \mathrm{H}_{2(\mathrm{~g})}\left(E^{\circ}=0.000 \mathrm{~V}\right)$ \\
\hline & Total: \\
\hline & $2 \mathrm{Fe}_{(\mathrm{s})}+6 \mathrm{H}_{2} \mathrm{O}_{(\mathrm{l})} \rightarrow \mathrm{O}_{2(\mathrm{~g})}+4 \mathrm{H}_{2(\mathrm{~g})}+2 \mathrm{Fe}(\mathrm{OH})_{2(\mathrm{~s})}$ \\
\hline \multirow{11}{*}{ Mechanism \#2 (pH 7) } & Anode: \\
\hline & $2 \mathrm{Fe}_{(\mathrm{s})}-4 \mathrm{e}^{-} \rightarrow 2 \mathrm{Fe}_{(\mathrm{aq})}^{2+}\left(E^{\circ}=+0.447 \mathrm{~V}\right)$ \\
\hline & $\mathrm{Fe}_{(\mathrm{aq})}^{2+}-\mathrm{e}^{-} \rightarrow \mathrm{Fe}_{(\mathrm{aq})}^{3+}\left(E^{\circ}=-0.771 \mathrm{~V}\right)$ \\
\hline & $\mathrm{Fe}_{(\mathrm{s})}-3 \mathrm{e}^{-} \rightarrow \mathrm{Fe}_{(\mathrm{aq})}^{3+}\left(E^{\circ}=+0.037 \mathrm{~V}\right)$ \\
\hline & Solution: \\
\hline & $\mathrm{Fe}_{(\mathrm{aq})}^{2+}+2 \mathrm{OH}_{(\mathrm{aq})}^{-} \rightarrow \mathrm{Fe}(\mathrm{OH})_{2(\mathrm{~s})}$ \\
\hline & $2 \mathrm{Fe}_{(\mathrm{aq})}^{3+}+6 \mathrm{OH}_{(\mathrm{aq})}^{-} \rightarrow 2 \mathrm{Fe}(\mathrm{OH})_{3(\mathrm{~s})}$ \\
\hline & Cathode: \\
\hline & $8 \mathrm{H}_{2} \mathrm{O}_{(1)}+8 \mathrm{e}^{-} \rightarrow 4 \mathrm{H}_{2(\mathrm{~g})}+8 \mathrm{OH}_{(\mathrm{aq})}^{-}\left(E^{\circ}=-0.828 \mathrm{~V}\right)$ \\
\hline & Total: \\
\hline & $3 \mathrm{Fe}_{(\mathrm{s})}+8 \mathrm{H}_{2} \mathrm{O}_{(\mathrm{l})} \rightarrow \mathrm{Fe}(\mathrm{OH})_{2(\mathrm{~s})}+2 \mathrm{Fe}(\mathrm{OH})_{3(\mathrm{~s})}+4 \mathrm{H}_{2(\mathrm{~g})}$ \\
\hline \multirow{8}{*}{ Mechanism \#3 ( $p H$ 12) } & Anode: \\
\hline & $2 \mathrm{Fe}_{(\mathrm{s})}-6 \mathrm{e}^{-} \rightarrow 2 \mathrm{Fe}_{(\mathrm{aq})}^{3+}\left(E^{\circ}=+0.037 \mathrm{~V}\right)$ \\
\hline & Solution: \\
\hline & $2 \mathrm{Fe}_{(\mathrm{aq})}^{3+}+6 \mathrm{OH}_{(\mathrm{aq})}^{-} \rightarrow 2 \mathrm{Fe}(\mathrm{OH})_{3(\mathrm{~s})}$ \\
\hline & Cathode: \\
\hline & $6 \mathrm{H}_{2} \mathrm{O}_{(\mathrm{l})}+6 \mathrm{e}^{-} \rightarrow 3 \mathrm{H}_{2(\mathrm{~g})}+6 \mathrm{OH}_{(\mathrm{aq})}^{-}\left(E^{\circ}=-0.828 \mathrm{~V}\right)$ \\
\hline & Total: \\
\hline & $2 \mathrm{Fe}_{(\mathrm{s})}+6 \mathrm{H}_{2} \mathrm{O}_{(\mathrm{l})} \rightarrow 2 \mathrm{Fe}(\mathrm{OH})_{3(\mathrm{~s})}+3 \mathrm{H}_{2(\mathrm{~g})}$ \\
\hline \multirow{12}{*}{ Mechanism $(p H 7)$} & Al mechanism \\
\hline & Anode: \\
\hline & $\mathrm{Al}_{(\mathrm{s})}-3 \mathrm{e}^{-} \rightarrow \mathrm{Al}_{(\mathrm{aq})}^{3+}\left(E^{\circ}=+1.66 \mathrm{~V}\right)$ \\
\hline & $2 \mathrm{H}_{2} \mathrm{O}_{(1)}-4 \mathrm{e}^{-} \rightarrow \mathrm{O}_{2(\mathrm{~g})}+4 \mathrm{H}_{(\mathrm{aq})}^{+}\left(E^{\circ}=-1.229 \mathrm{~V}\right)$ \\
\hline & Solution: \\
\hline & $\mathrm{Al}_{(\mathrm{aq})}^{3+}+3 \mathrm{OH}_{(\mathrm{aq})}^{-} \rightarrow \mathrm{Al}(\mathrm{OH})_{3(\mathrm{~s})}$ \\
\hline & $\mathrm{Al}(\mathrm{OH})_{4(\mathrm{aq})}^{-} \rightarrow \mathrm{OH}_{(\mathrm{aq})}^{-}+\mathrm{Al}(\mathrm{OH})_{3(\mathrm{~s})}$ \\
\hline & Cathode: \\
\hline & $4 \mathrm{H}_{2} \mathrm{O}_{(1)}+4 \mathrm{e}^{-} \rightarrow 2 \mathrm{H}_{2(\mathrm{~g})}+4 \mathrm{OH}_{(\mathrm{aq})}^{-}\left(E^{\circ}=-0.828 \mathrm{~V}\right)$ \\
\hline & $\mathrm{Al}_{(\mathrm{s})}+4 \mathrm{OH}_{(\mathrm{aq})}^{-}-3 \mathrm{e}^{-} \rightarrow \mathrm{Al}(\mathrm{OH})_{4(\text { (aq) }}^{-}$ \\
\hline & Total: \\
\hline & $2 \mathrm{Al}_{(\mathrm{s})}+8 \mathrm{H}_{2} \mathrm{O}_{(1)} \rightarrow 5 \mathrm{H}_{2(\mathrm{~g})}+2 \mathrm{Al}(\mathrm{OH})_{3(\mathrm{~s})}+\mathrm{O}_{2(\mathrm{~g})}$ \\
\hline
\end{tabular}


virus reduction in natural waters. In pointing out virus removal, $\Phi$ X174 was the only bacteriophage surrogate resistant to ferrous demobilization, probably because of electrostatic repulsion between $\Phi \mathrm{X} 174$ and $\mathrm{Fe}^{2+}$ at $\mathrm{pH} 6$ and/or shielding of $\Phi$ X174 virions in aggregates near neutral pH. Even if electrostatic interactions between $\mathrm{Fe}^{2+}$ and virions possibly interpret at least some of the distinctions in killing performance between viruses, resistant viruses also had thicker capsids. Heffron et al. [5] concluded that the shortage of measured IEP information for human viruses blocks a comprehensive examination of such supposition, even if an exhaustive theoretical estimation of capsid structure could furnish further comprehension where experimental procedures are restrictive.

To disinfect water, ultrafiltration (UF) has been shown to be performant; however, the technique was influenced by the aqueous matrix and thus, limited reduction of bacteriophage PP7 was reached [119]. The occurrence of divalent cations decreased the performance as compared to monovalent cations and species with amphoteric behavior like bicarbonate. Gentile et al. [119] found that size of the bacteriophage did not change greatly with $\mathrm{pH}$ or ionic strength. Besides, at circumnatural $\mathrm{pH}$ (i.e., from 5 to 8 ) viruses constitute small aggregates, turning off UF treatment. Small energy barriers were reached for $\mathrm{NaCl}$ and $\mathrm{NaHCO}_{3}$ at $100 \mathrm{mM}$. For 1 and $10 \mathrm{mM}$ background solutions, electrostatic repulsion was anticipated. The viral elimination augmented in this order: $\mathrm{Mg}^{2+}, \mathrm{Ca}^{2+}$, and $\mathrm{Na}^{+}$ with $\mathrm{HCO}_{3}^{-}$. For PP7, modifications in $\mathrm{pH}$ ranged between 5 and 8 (far from the virus IEP) or ionic strength did not change the modeling forecasts concerning stability and attachment. Such findings called attention to the significance of electrostatic repulsion in improving virus elimination by membrane filtration.

Concerning the question addressed above, it is difficult now that modeling IEPs for viruses could be employed in assessing the needed EF application. Controlling parameters such as $\mathrm{pH}$ and aqueous matrix, which is usually complicated due to NOM occurrence and metal-scavenging anions and complexation agents (like phosphates, citrates, carbonates and sulfates), remains difficult. Such chemicals, as mentioned above, are responsible of decreased coagulant generation or pathogens reduction [5] [84] [106] [107].

\section{Conclusions}

In both nature and physicochemical treatment, virus end depends on electrostatic interactions. Suggesting an exact method of predicting virion isoelectric point (IEP) would assist to comprehend and predict virus end. To predict IEP, an easy method evaluates the $\mathrm{pH}$ at which the sum of charges from ionizable amino acids in capsid proteins reaches zero. Founded on capsid charges, however, predicted IEPs usually diverge by some $\mathrm{pH}$ units from experimentally measured IEPs. Such disparity between experimental and predicted IEP was in fact ascribed to the electrostatic neutralization of predictable polynucleotide-binding regions (PBRs) of the capsid interior. In this work, models assuming the 1) effect of the viral polynucleotide on the surface charge, or 2) contribution of only exterior residues 
to surface charge are discussed. Such models are relevant to non-enveloped viruses only, and an identical model for enveloped viruses remains complex by the deficiency of information on enveloped virus IEP and uncertainties concerning the effect of the phospholipid envelope on charge and ion gradients [1].

Concerning the interrogation if viruses' IEPs modeling will be employed in assessing the needed EF application, it is difficult now that modeling IEPs for viruses could be employed in assessing the needed EF application. Controlling parameters such as $\mathrm{pH}$ and aqueous matrix, which is usually complicated due to NOM occurrence and metal-scavenging anions and complexation agents (like phosphates, citrates, carbonates and sulfates), remains difficult. Such chemicals are responsible of decreased coagulant generation or pathogens reduction.

\section{Acknowledgements}

The Research Deanship of University of Ha'il, Saudi Arabia, has funded this research through the Project RG-20113.

\section{Conflicts of Interest}

The authors declare no conflicts of interest regarding the publication of this paper.

\section{References}

[1] Heffron, J. and Mayer, B.K. (2020) Theories and Methods of Virus Isoelectric Point Estimation (Minireview). Applied and Environmental Microbiology.

[2] Heffron, J. and Mayer, B.K. (2020) Improved Virus Isoelectric Point Estimation by Exclusion of Known and Predicted Genome-Binding Regions. Applied and Environmental Microbiology, 86, e01674-e01620. https://doi.org/10.1128/AEM.01674-20

[3] Zerda, K.S., Gerba, C.P., Hou, K.C. and Goyal, S.M. (1985) Adsorption of Viruses to Charge-Modified Silica. Applied and Environmental Microbiology, 49, 91-95. https://doi.org/10.1128/AEM.49.1.91-95.1985

[4] Heffron, J. and Mayer, B.K. (2016) Virus Mitigation by Coagulation: Recent Discoveries and Future Directions. Environmental Science: Water Research \& Technology, 2, 443-459. https://doi.org/10.1039/C6EW00060F

[5] Heffron, J., McDermid, B., Maher, E., McNamara, P. and Mayer, B.K. (2019) Mechanisms of Virus Mitigation and Suitability of Bacteriophages as Surrogates in Drinking Water Treatment by Iron Electrocoagulation. Water Research, 163, Article ID: 114877. https://doi.org/10.1016/j.watres.2019.114877

[6] Mattle, M.J., Crouzy, B., Brennecke, M., Wigginton, K.R., Perona, P. and Kohn, T. (2011) Impact of Virus Aggregation on Inactivation by Peracetic Acid and Implications for Other Disinfectants. Environmental Science \& Technology, 45, 7710-7717. https://doi.org/10.1021/es201633s

[7] Gerba, C.P. and Betancourt, W.Q. (2017) Viral Aggregation: Impact on Virus Behavior in the Environment. Environmental Science \& Technology, 51, 7318-7325. https://doi.org/10.1021/acs.est.6b05835

[8] Dika, C., Duval, J.F.L., Francius, G., Perrin, A. and Gantzer, C. (2015) Isoelectric Point Is an Inadequate Descriptor of MS2, Phi X 174 and PRD1 Phages Adhesion 
on Abiotic Surfaces. Journal of Colloid and Interface Science, 446, 327-334. https://doi.org/10.1016/j.jcis.2014.08.055

[9] Yuan, B., Pham, M. and Nguyen, T.H. (2008) Deposition Kinetics of Bacteriophage MS2 on a Silica Surface Coated with Natural Organic Matter in a Radial Stagnation Point Flow Cell. Environmental Science \& Technology, 42, 7628-7633. https://doi.org/10.1021/es801003s

[10] Horká, M., Kubíček, O., Růžička, F., Holá, V., Malinovská, I. and Šlais, K. (2007) Capillary Isoelectric Focusing of Native and Inactivated Microorganisms. Journal of Chromatography A, 1155, 164-171. https://doi.org/10.1016/j.chroma.2007.02.026

[11] Brorson, K., Shen, H., Lute, S., Pérez, J.S. and Frey, D.D. (2008) Characterization and Purification of Bacteriophages Using Chromatofocusing. Journal of Chromatography $A$, 1207, 110-121. https://doi.org/10.1016/j.chroma.2008.08.037

[12] Cashdollar, J.L. and Wymer, L. (2013) Methods for Primary Concentration of Viruses from Water Samples: A Review and Meta-Analysis of Recent Studies. Journal of Applied Microbiology, 115, 1-11. https://doi.org/10.1111/jam.12143

[13] Polaczyk, A.L., Roberts, J.M. and Hill, V.R. (2007) Evaluation of 1MDS Electropositive Microfilters for Simultaneous Recovery of Multiple Microbe Classes from Tap Water. The Journal of Microbiological Methods, 68, 260-266. https://doi.org/10.1016/j.mimet.2006.08.007

[14] Gutiérrez, L., Mylon, S.E., Nash, B. and Nguyen, T.H. (2010) Deposition and Aggregation Kinetics of Rotavirus in Divalent Cation Solutions. Environmental Science \& Technology, 44, 4552-4557. https://doi.org/10.1021/es100120k

[15] Mayer, B.K., Yang, Y., Gerrity, D.W. and Abbaszadegan, M. (2015) The Impact of Capsid Proteins on Virus Removal and Inactivation during Water Treatment Processes. Microbiology Insights, 8, 15-28. https://doi.org/10.4137/MBI.S31441

[16] Armanious, A., Aeppli, M., Jacak, R., Refardt, D., Sigstam, T., Kohn, T. and Sander, M. (2016) Viruses at Solid-Water Interfaces: A Systematic Assessment of Interactions Driving Adsorption. Environmental Science \& Technology, 50, 732-743. https://doi.org/10.1021/acs.est.5b04644

[17] Božič, A.L., Šiber, A. and Podgornik, R. (2012) How Simple Can a Model of an Empty Viral Capsid Be? Charge Distributions in Viral Capsids. Journal of Biological Physics, 38, 657-671. https://doi.org/10.1007/s10867-012-9278-4

[18] Penrod, S.L., Olson, T.M. and Grant, S.B. (1996) Deposition Kinetics of Two Viruses in Packed Beds of Quartz Granular Media. Langmuir, 12, 5576-5587. https://doi.org/10.1021/la950884d

[19] Schaldach, C.M., Bourcier, W.L., Shaw, H.F., Viani, B.E. and Wilson, W.D. (2006) The Influence of Ionic Strength on the Interaction of Viruses with Charged Surfaces under Environmental Conditions. Journal of Colloid and Interface Science, 294, 1-10. https://doi.org/10.1016/j.jcis.2005.06.082

[20] Michen, B. and Graule, T. (2010) Isoelectric Points of Viruses. Journal of Applied Microbiology, 109, 388-397. https://doi.org/10.1111/j.1365-2672.2010.04663.x

[21] Kozlowski, L.P. (2017) Proteome-pI: Proteome Isoelectric Point Database. Nucleic Acids Research, 45, D1112-D1116. https://doi.org/10.1093/nar/gkw978

[22] Duval, J.F.L. and Ohshima, H. (2006) Electrophoresis of Soft Particles. Langmuir, 22, 3533-3546. https://doi.org/10.1021/la0528293

[23] Nap, R.J., Božič, A.L., Szleifer, I. and Podgornik, R. (2014) The Role of Solution Conditions in the Bacteriophage PP7 Capsid Charge Regulation. Biophysical Journal, 107, 1970-1979. https://doi.org/10.1016/j.bpj.2014.08.032 
[24] Ryan, D.R., Maher, E.K., Heffron, J., Mayer, B.K. and McNamara, P.J. (2021) Electrocoagulation-Electrooxidation for Mitigating Trace Organic Compounds in Model Drinking Water Sources. Chemosphere, 273, 129377. https://doi.org/10.1016/j.chemosphere.2020.129377

[25] Šiber, A. and Podgornik, R. (2008) Nonspecific Interactions in Spontaneous Assembly of Empty Versus Functional Single-Stranded RNA Viruses. Physical Review E, 78, Article ID: 051915. https://doi.org/10.1103/PhysRevE.78.051915

[26] Ghernaout, D., Elboughdiri, N. and Al Arni, S. (2020) New Insights towards Disinfecting Viruses-Short Notes. Journal of Water Reuse and Desalination, 10, 173-186. https://doi.org/10.2166/wrd.2020.050

[27] Ghernaout, D. and Elboughdiri, N. (2020) Environmental Engineering for Stopping Viruses Pandemics. Open Access Library Journal, 7, e6299.

https://doi.org/10.4236/oalib.1106299

[28] Bhowmick, G.D., Dhar, D., Nath, D., Ghangrekar, M.M., Banerjee, R., Das, S. and Chatterjee, J. (2020) Coronavirus Disease 2019 (COVID-19) Outbreak: Some Serious Consequences with Urban and Rural Water Cycle. NPJ Clean Water, 3, 32. https://doi.org/10.1038/s41545-020-0079-1

[29] Kotwal, G. and Cannon, J.L. (2014) Environmental Persistence and Transfer of Enteric Viruses. Current Opinion in Virology, 4, 37-43. https://doi.org/10.1016/j.coviro.2013.12.003

[30] Ghernaout, D. and Elboughdiri, N. (2020) On the Other Side of Viruses in the Background of Water Disinfection. Open Access Library Journal, 7, e6374. https://doi.org/10.4236/oalib.1106374

[31] Ghernaout, D. (2020) Water Treatment Challenges towards Viruses Removal. Open Access Library Journal, 7, e6408. https://doi.org/10.4236/oalib.1106408

[32] Abrescia, N.G.A., Grimes, J.M., Kivelä, H.M., Assenberg, R., Sutton, G.C., Butcher, S.J., Bamford, J.K.H., Bamford, D.H. and Stuart, D.I. (2008) Insights into Virus Evolution and Membrane Biogenesis from the Structure of the Marine Lipid-Containing Bacteriophage PM2. Molecular Cell, 31, 749-761.

https://doi.org/10.1016/j.molcel.2008.06.026

[33] Abrescia, N.G.A., Cockburn, J.J.B., Grimes, J.M., Sutton, G.C., Diprose, J.M., Butcher, S.J., Fuller, S.D., San Martín, C., Burnett, R.M., Stuart, D.I., Bamford, D.H. and Bamford, J.K.H. (2004) Insights into Assembly from Structural Analysis of Bacteriophage PRD1. Nature, 432, 68-74. https://doi.org/10.1038/nature03056

[34] Wigginton, K.R., Ye, Y. and Ellenberg, R.M. (2015) Emerging Investigators Series: The Source and Fate of Pandemic Viruses in the Urban Water Cycle. Environmental Science: Water Research \& Technology, 1, 735-746. https://doi.org/10.1039/C5EW00125K

[35] Ye, Y., Ellenberg, R.M., Graham, K.E. and Wigginton, K.R. (2016) Survivability, Partitioning, and Recovery of Enveloped Viruses in Untreated Municipal Wastewater. Environmental Science \& Technology, 50, 5077-5085. https://doi.org/10.1021/acs.est.6b00876

[36] Ghernaout, D. (2019) Virus Removal by Electrocoagulation and Electrooxidation: New Findings and Future Trends. Journal of Environmental Science and Allied Research, 2019, 85-90. https://doi.org/10.29199/2637-7063/ESAR-202024

[37] Ghernaout, D. and Elboughdiri, N. (2020) Urgent Proposals for Disinfecting Hospital Wastewaters during COVID-19 Pandemic. Open Access Library Journal, 7, e6373. https://doi.org/10.4236/oalib.1106373

[38] Ghernaout, D. and Ghernaout, B. (2020) Controlling COVID-19 Pandemic through 
Wastewater Monitoring. Open Access Library Journal, 7, e6411. https://doi.org/10.4236/oalib.1106411

[39] Tsui, F.C., Ojcius, D.M. and Hubbell, W.L. (1986) The Intrinsic $\mathrm{p} K_{\mathrm{a}}$ Values for Phosphatidylethanolamine Phosphatidylcholine Bilayers. Biophysical Journal, 49, 459-468. https://doi.org/10.1016/S0006-3495(86)83655-4

[40] Ivanova, P.T., Myers, D.S., Milne, S.B., McClaren, J.L., Thomas, P.G. and Brown, H.A. (2015) Lipid Composition of Viral Envelope of Three Strains of Influenza Virus-Not All Viruses Are Created Equal. ACS Infectious Diseases, 1, 435-442. https://doi.org/10.1021/acsinfecdis.5b00040

[41] Kim, H.J., Kwag, H.L. and Kim, H.J. (2016) Characterization of Human Papillomavirus Type 16 Pseudovirus Containing Histones. BMC Biotechnology, 16, Article No. 63. https://doi.org/10.1186/s12896-016-0296-3

[42] Zerda, K.S. and Gerba, C.P. (1984) Agraose Isoelectrofocusing of Intact Virions. The Journal of Virological Methods, 9, 1-6. https://doi.org/10.1016/0166-0934(84)90077-6

[43] Douglas, H.W. and Williams, B.L. (1969) Micro-Electrophoresis of Poxviruses in Molar Sucrose. Journal of General Virology, 5, 391-396.

https://doi.org/10.1099/0022-1317-5-3-391

[44] Douglas, H.W., Rondle, C.J. and Williams, B.L. (1966) Micro-Electrophoresis of Cowpox and Vaccinia Viruses in Molar Sucrose. The Journal of General Microbiology, 42, 107-113. https://doi.org/10.1099/00221287-42-1-107

[45] Mouillot, L. and Netter, R. (1977) Identification of Orthopox Virus by Isoelectrofocusing in a Granulated Gel. Annals of Microbiology (Paris), 128, 417-419.

[46] Moss, B. (2012) Poxvirus Cell Entry: How Many Proteins Does It Take? Viruses, 4, 688-707. https://doi.org/10.3390/v4050688

[47] Wasilewski, S., Calder, L.J., Grant, T. and Rosenthal, P.B. (2012) Distribution of Surface Glycoproteins on Influenza A Virus Determined by Electron Cryotomography. Vaccine, 30, 7368-7373. https://doi.org/10.1016/j.vaccine.2012.09.082

[48] Schoeman, D. and Fielding, B.C. (2019) Coronavirus Envelope Protein: Current Knowledge. Virology Journal, 16, Article No. 69.

https://doi.org/10.1186/s12985-019-1182-0

[49] Taylor, D.H. and Bosmann, H.B. (1981) The Electrokinetic Properties of Reovirus Type 3: Electrophoretic Mobility and Zeta Potential in Dilute Electrolytes. Journal of Colloid and Interface Science, 83, 153-162. https://doi.org/10.1016/0021-9797(81)90020-5

[50] Schäfer, R., Hinnen, R. and Franklin, R.M. (1974) Structure and Synthesis of a Lipid-Containing Bacteriophage: Properties of the Structural Proteins and Distribution of the Phospholipid. European Journal of Biochemistry, 50, 15-27. https://doi.org/10.1111/j.1432-1033.1974.tb03868.x

[51] The UniProt Consortium (2019) UniProt: A Worldwide Hub of Protein Knowledge. Nucleic Acids Research, 47, D506-D515. https://doi.org/10.1093/nar/gky1049

[52] Sayers, E.W., Barrett, T., Benson, D.A., Bryant, S.H., Canese, K., Chetvernin, V., Church, D.M., Dicuccio, M., Edgar, R., Federhen, S., Feolo, M., Geer, L.Y., Helmberg, W., Kapustin, Y., Landsman, D., Lipman, D.J., Madden, T.L., Maglott, D.R., Miller, V., Mizrachi, I., Ostell, J., Pruitt, K.D., Schuler, G.D., Sequeira, E., Sherry, S.T., Shumway, M., Sirotkin, K., Souvorov, A., Starchenko, G., Tatusova, T.A., Wagner, L., Yaschenko, E. and Ye, J. (2009) Database Resources of the National Center for Biotechnology Information. Nucleic Acids Research, 37, D5-D15. https://doi.org/10.1093/nar/gkn741 
[53] Berman, H.M., Westbrook, J., Feng, Z., Gilliland, G., Bhat, T.N., Weissig, H., Shindyalov, I.N. and Bourne, P.E. (2000) The Protein Data Bank. Nucleic Acids Research, 28, 235-242. https://doi.org/10.1093/nar/28.1.235

[54] Kalko, S.G., Cachau, R.E. and Silva, A.M. (1992) Ion Channels in Icosahedral Virus: A Comparative Analysis of the Structures and Binding Sites at Their Fivefold Axes. Biophysical Journal, 63, 1133-1145. https://doi.org/10.1016/S0006-3495(92)81693-4

[55] Silva, A.M., Cachau, R.E. and Goldstein, D.J. (1987) Ion Channels in Southern Bean Mosaic Virus Capsid. Biophysical Journal, 52, 595-602. https://doi.org/10.1016/S0006-3495(87)83249-6

[56] Ghernaout, D. and Elboughdiri, N. (2019) Electrocoagulation Process Intensification for Disinfecting Water-A Review. Applied Engineering, 3, 140-147.

[57] Ghernaout, D. and Ghernaout, B. (2010) From Chemical Disinfection to Electrodisinfection: The Obligatory Itinerary? Desalination and Water Treatment, 16, 156-175. https://doi.org/10.5004/dwt.2010.1085

[58] Ghernaout, D. (2020) Demobilizing Antibiotic-Resistant Bacteria and Antibiotic Resistance Genes by Electrochemical Technology: New Insights. Open Access Library Journal, 7, e6685. https://doi.org/10.4236/oalib.1106685

[59] Ghernaout, D. and Elboughdiri, N. (2020) Electrochemical Technology for Wastewater Treatment: Dares and Trends. Open Access Library Journal, 7, e6020. https://doi.org/10.4236/oalib.1106020

[60] Ghernaout, D. (2019) Electrocoagulation and Electrooxidation for Disinfecting Water: New Breakthroughs and Implied Mechanisms. Applied Engineering, 3, 125-133.

[61] Ghernaout, D. and Elboughdiri, N. (2020) Electrocoagulation Process in the Context of Disinfection Mechanism. Open Access Library Journal, 7, e6083. https://doi.org/10.4236/oalib.1106083

[62] Ghernaout, D. and Elboughdiri, N. (2019) Mechanistic Insight into Disinfection Using Ferrate(VI). Open Access Library Journal, 6, e5946. https://doi.org/10.4236/oalib.1105946

[63] Ghernaout, D. and Elboughdiri, N. (2019) Water Disinfection: Ferrate(VI) as the Greenest Chemical-A Review. Applied Engineering, 3, 171-180.

[64] Ghernaout, D. and Naceur, M.W. (2011) Ferrate(VI): In Situ Generation and Water Treatment-A Review. Desalination and Water Treatment, 30, 319-332. https://doi.org/10.5004/dwt.2011.2217

[65] Ghernaout, D., Elboughdiri, N. and Ghareba, S. (2020) Fenton Technology for Wastewater Treatment: Dares and Trends. Open Access Library Journal, 7, e6045. https://doi.org/10.4236/oalib.1106045

[66] Ghernaout, D., Badis, A., Ghernaout, B. and Kellil, A. (2008) Application of Electrocoagulation in Escherichia coli Culture and Two Surface Waters. Desalination, 219, 118-125. https://doi.org/10.1016/j.desal.2007.05.010

[67] Ghernaout, D., Elboughdiri, N., Ghareba, S. and Salih, A. (2020) Electrochemical Advanced Oxidation Processes (EAOPs) for Disinfecting Water-Fresh Perspectives. Open Access Library Journal, 7, e6257. https://doi.org/10.4236/oalib.1106257

[68] Ghernaout, D. and Elboughdiri, N. (2020) Advanced Oxidation Processes for Wastewater Treatment: Facts and Future Trends. Open Access Library Journal, 7, e6139. https://doi.org/10.4236/oalib.1106139

[69] Ghernaout, D. (2013) Advanced Oxidation Phenomena in Electrocoagulation Process: A Myth or a Reality? Desalination and Water Treatment, 51, 7536-7554. https://doi.org/10.1080/19443994.2013.792520 
[70] Ghernaout, D., Elboughdiri, N., Alghamdi, A. and Ghernaout, B. (2020) Trends in Decreasing Disinfection By-Products Formation during Electrochemical Technologies. Open Access Library Journal, 7, e6337. https://doi.org/10.4236/oalib.1106337

[71] Ghernaout, D. and Elboughdiri, N. (2020) Disinfection By-Products Regulation: Zero ng/L Target. Open Access Library Journal, 7, e6382.

https://doi.org/10.4236/oalib.1106382

[72] Ghernaout, D. and Elboughdiri, N. (2020) Disinfection By-Products (DBPs) Control Strategies in Electrodisinfection. Open Access Library Journal, 7, e6396. https://doi.org/10.4236/oalib.1106396

[73] Ghernaout, D. and Elboughdiri, N. (2020) Foresight Look on the Disinfection ByProducts Formation. Open Access Library Journal, 7, e6349.

https://doi.org/10.4236/oalib.1106349

[74] Ghernaout, D. and Elboughdiri, N. (2020) Disinfection By-Products: Presence and Elimination in Drinking Water. Open Access Library Journal, 7, e6140. https://doi.org/10.4236/oalib.1106140

[75] Ghernaout, D. and Elboughdiri, N. (2020) Should We Forbid the Consumption of Antibiotics to Stop the Spread of Resistances in Nature? Open Access Library Journal, 7, e6138. https://doi.org/10.4236/oalib.1106138

[76] Ghernaout, D. (2020) Electric Field (EF) in the Core of the Electrochemical (EC) Disinfection. Open Access Library Journal, 7, e6587.

https://doi.org/10.4236/oalib.1106587

[77] Ghernaout, D. (2020) Electrocoagulation as a Pioneering Separation TechnologyElectric Field Role. Open Access Library Journal, 7, e6702. https://doi.org/10.4236/oalib.1106702

[78] Ghernaout, D., Boudjemline, A. and Elboughdiri, N. (2020) Electrochemical Engineering in the Core of the Dye-Sensitized Solar Cells (DSSCs). Open Access Library Journal, 7, e6178. https://doi.org/10.4236/oalib.1106178

[79] Ghernaout, D. and Elboughdiri, N. (2020) An Insight in Electrocoagulation Process through Current Density Distribution (CDD). Open Access Library Journal, 7, e6142.

[80] Ghernaout, D. (2017) Microorganisms' Electrochemical Disinfection Phenomena. EC Microbiology, 9, 160-169.

[81] Ghernaout, D. (2020) Charge Neutralization in the Core of Plasma Treatment. Open Access Library Journal, 7, e6434. https://doi.org/10.4236/oalib.1106434

[82] Ghernaout, D. and Ghernaout, B. (2012) Sweep Flocculation as a Second Form of Charge Neutralisation-A Review. Desalination and Water Treatment, 44, 15-28. https://doi.org/10.1080/19443994.2012.691699

[83] Ghernaout, D., Touahmia, M. and Aichouni, M. (2019) Disinfecting Water: Electrocoagulation as an Efficient Process. Applied Engineering, 3, 1-12.

[84] Ghernaout, D., Aichouni, M. and Touahmia, M. (2019) Mechanistic Insight into Disinfection by Electrocoagulation-A Review. Desalination and Water Treatment, 141, 68-81. https://doi.org/10.5004/dwt.2019.23457

[85] Ghernaout, D. (2019) Disinfection via Electrocoagulation Process: Implied Mechanisms and Future Tendencies. EC Microbiology, 15, 79-90.

[86] Ghernaout, D. (2020) Natural Organic Matter Removal in the Context of the Performance of Drinking Water Treatment Processes-Technical Notes. Open Access Library Journal, 7, e6751. https://doi.org/10.4236/oalib.1106751

[87] Ghernaout, D., Ghernaout, B. and Kellil, A. (2009) Natural Organic Matter Removal 
and Enhanced Coagulation as a Link between Coagulation and Electrocoagulation. Desalination and Water Treatment, 2, 203-222. https://doi.org/10.5004/dwt.2009.116

[88] Ghernaout, D., Naceur, M.W. and Ghernaout, B. (2011) A Review of Electrocoagulation as a Promising Coagulation Process for Improved Organic and Inorganic Matters Removal by Electrophoresis and Electroflotation. Desalination and Water Treatment, 28, 287-320. https://doi.org/10.5004/dwt.2011.1493

[89] Ghernaout, D., Alghamdi, A. and Ghernaout, B. (2019) Microorganisms' Killing: Chemical Disinfection vs. Electrodisinfection. Applied Engineering, 3, 13-19.

[90] Ghernaout, D., Elboughdiri, N., Ghareba, S. and Salih, A. (2020) Disinfecting Water with the Carbon Fiber-Based Flow-Through Electrode System (FES): Towards Axial Dispersion and Velocity Profile. Open Access Library Journal, 7, e6238.

https://doi.org/10.4236/oalib.1106238

[91] Ghernaout, D., Benblidia, C. and Khemici, F. (2015) Microalgae Removal from Ghrib Dam (Ain Defla, Algeria) Water by Electroflotation Using Stainless Steel Electrodes. Desalination and Water Treatment, 54, 3328-3337.

https://doi.org/10.1080/19443994.2014.907749

[92] Ghernaout, D., Naceur, M.W. and Aouabed, A. (2011) On the Dependence of Chlorine By-Products Generated Species Formation of the Electrode Material and Applied Charge during Electrochemical Water Treatment. Desalination, 270, 9-22. https://doi.org/10.1016/j.desal.2011.01.010

[93] Ghernaout, D. and Elboughdiri, N. (2020) Is Not It Time to Stop Using Chlorine for Treating Water? Open Access Library Journal, 7, e6007.

https://doi.org/10.4236/oalib.1106007

[94] Ghernaout, D. (2019) Greening Electrocoagulation Process for Disinfecting Water. Applied Engineering, 3, 27-31.

[95] Ghernaout, D., Ghernaout, B. and Naceur, M.W. (2011) Embodying the Chemical Water Treatment in the Green Chemistry-A Review. Desalination, 271, 1-10. https://doi.org/10.1016/j.desal.2011.01.032

[96] Belhout, D., Ghernaout, D., Djezzar-Douakh, S. and Kellil, A. (2010) Electrocoagulation of a Raw Water of Ghrib Dam (Algeria) in Batch Using Iron Electrodes. Desalination and Water Treatment, 16, 1-9. https://doi.org/10.5004/dwt.2010.1081

[97] Ghernaout, D. and Elboughdiri, N. (2020) Antibiotics Resistance in Water Mediums: Background, Facts, and Trends. Applied Engineering, 4, 1-6.

[98] Ghernaout, D. and Elboughdiri, N. (2020) Removing Antibiotic-Resistant Bacteria (ARB) Carrying Genes (ARGs): Challenges and Future Trends. Open Access Library Journal, 7, e6003. https://doi.org/10.4236/oalib.1106003

[99] Ghernaout, D. (2008) Élimination des substances humiques et des germes indicateurs de contamination bactériologique par électrocoagulation assistée d'un traitement magnétique de l'eau. Ph.D. Thesis, University of Blida, Algeria.

[100] Ghernaout, D. and Elboughdiri, N. (2020) Solar Treatment in the Core of the New Disinfection Technologies. Chemical Science and Engineering Research, 2, 6-11.

[101] Ghernaout, D. and Elboughdiri, N. (2020) Vacuum-UV Radiation at $185 \mathrm{~nm}$ for Disinfecting Water. Chemical Science and Engineering Research, 2, 12-17.

[102] Ghernaout, D. and Elboughdiri, N. (2020) UV-C/ $/ \mathrm{H}_{2} \mathrm{O}_{2}$ and Sunlight $/ \mathrm{H}_{2} \mathrm{O}_{2}$ in the Core of the Best Available Technologies for Dealing with Present Dares in Domestic Wastewater Reuse. Open Access Library Journal, 7, e6161.

https://doi.org/10.4236/oalib.1106161 
[103] Ghernaout, D. and Elboughdiri, N. (2019) Iron Electrocoagulation Process for Disinfecting Water-A Review. Applied Engineering, 3, 154-158.

[104] Tanneru, C.T., Jothikumar, N., Hill, V.R. and Chellam, S. (2014) Relative Insignificance of Virus Inactivation during Aluminum Electrocoagulation of Saline Waters. Environmental Science \& Technology, 48, 14590-14598. https://doi.org/10.1021/es504381f

[105] Ghernaout, D. and Elboughdiri, N. (2020) Strategies for Reducing Disinfection ByProducts Formation during Electrocoagulation. Open Access Library Journal, 7, e6076. https://doi.org/10.4236/oalib.1106076

[106] Bicudo, B., van Halem, D., Trikannad, S.A., Ferrero, G. and Medema, G. (2021) Low Voltage Iron Electrocoagulation as a Tertiary Treatment of Municipal Wastewater: Removal of Enteric Pathogen Indicators and Antibiotic-Resistant Bacteria. Water Research, 188, Article ID: 116500. https://doi.org/10.1016/j.watres.2020.116500

[107] van Genuchten, C.M., Dalby, K.N., Ceccato, M., Stipp, S.L.S. and Dideriksen, K. (2017) Factors Affecting the Faradaic Efficiency of Fe(0) Electrocoagulation. Journal of Environmental Chemical Engineering, 5, 4958-4968.

https://doi.org/10.1016/j.jece.2017.09.008

[108] Anfruns-Estrada, E., Bruguera-Casamada, C., Salvadó, H., Brillas, E., Sirés, I. and Araujo, R.M. (2017) Inactivation of Microbiota from Urban Wastewater by Single and Sequential Electrocoagulation and Electro-Fenton Treatments. Water Research, 126, 450-459. https://doi.org/10.1016/j.watres.2017.09.056

[109] Delaire, C., van Genuchten, C.M., Amrose, S.E. and Gadgil, A.J. (2016) Bacteria Attenuation by Iron Electrocoagulation Governed by Interactions between Bacterial Phosphate Groups and Fe(III) Precipitates. Water Research, 103, 74-82. https://doi.org/10.1016/j.watres.2016.07.020

[110] Delaire, C., van Genuchten, C.M., Nelson, K.L., Amrose, S.E. and Gadgil, A.J. (2015) Escherichia coli Attenuation by Fe Electrocoagulation in Synthetic Bengal Groundwater: Effect of $\mathrm{pH}$ and Natural Organic Matter. Environmental Science \& Technology, 49, 9945-9953. https://doi.org/10.1021/acs.est.5b01696

[111] Tanneru, C.T. and Chellam, S. (2012) Mechanisms of Virus Control during Iron Electrocoagulation-Microfiltration of Surface Water. Water Research, 46, 2111-2120. https://doi.org/10.1016/j.watres.2012.01.032

[112] Jeong, J., Kim, J.Y. and Yoon, J. (2006) The Role of Reactive Oxygen Species in the Electrochemical Inactivation of Microorganisms. Environmental Science \& Technology, 40, 6117-6122. https://doi.org/10.1021/es0604313

[113] Heffron, J., McDermid, B. and Mayer, B.K. (2019) Bacteriophage Inactivation as a Function of Ferrous Iron Oxidation. Environmental Science: Water Research \& Technology, 5, 1309-1317. https://doi.org/10.1039/C9EW00190E

[114] van Genuchten, C.M. and Peña, J. (2017) Mn(II) Oxidation in Fenton and Fenton type Systems: Identification of Reaction Efficiency and Reaction Products. Environmental Science \& Technology, 51, 2982-2991.

https://doi.org/10.1021/acs.est.6b05584

[115] Hug, S.J. and Leupin, O. (2003) Iron-Catalyzed Oxidation of Arsenic(III) by Oxygen and by Hydrogen Peroxide: pH-Dependent Formation of Oxidants in the Fenton Reaction. Environmental Science \& Technology, 37, 2734-2742. https://doi.org/10.1021/es026208x

[116] Hakizimana, J.N., Najid, N., Gourich, B., Vial, C., Stiriba, Y. and Naja, J. (2017) Hybrid Electrocoagulation/Electroflotation/Electrodisinfection Process as a Pretreatment for Seawater Desalination. Chemical Engineering Science, 170, 530-541. 


\section{https://doi.org/10.1016/j.ces.2017.04.029}

[117] Chellam, S. and Sari, M.A. (2016) Aluminum Electrocoagulation as Pretreatment during Microfiltrationof Surface Water Containing NOM: A Review of Fouling, NOM, DBP, and Virus Control. Journal of Hazardous Materials, 304, 490-501. https://doi.org/10.1016/j.jhazmat.2015.10.054

[118] Boudjema, N., Drouiche, N., Abdi, N., Grib, H., Lounici, H., Pauss, A. and Mameri, N. (2014) Treatment of Oued El Harrach River Water by Electrocoagulation Noting the Effect of the Electric Field on Microorganisms. Journal of the Taiwan Institute of Chemical Engineers, 45, 1564-1570. https://doi.org/10.1016/j.jtice.2013.10.006

[119] Gentile, G.J., Cruz, M.C., Rajal, V.B. and de Cortalezzi, M.M.F. (2018) Electrostatic Interactions in Virus Removal by Ultrafiltration Membranes. Journal of Environmental Chemical Engineering, 6, 1314-1321.

https://doi.org/10.1016/j.jece.2017.11.041 